JURNAL ILMIAH KOMPUTERISASI AKUNTANSI, Vol. 13, No. 2, Desember 2020, pp. 1 - 10

p-ISSN : 1979-116X (print)

e-ISSN : 2614-8870 (online)

http://journal.stekom.ac.id/index.php/kompak

- page 1

\title{
SISTEM INFORMASI ARUS KAS BERBASIS MULTI USER PADA SEKOLAH KB-TK KRISTEN DIAN WACANA DEMAK
}

\author{
Kasih Prrwantini $^{1}$, Elisa Satyaningrum ${ }^{2}$, Arsito Ari Kuncoro ${ }^{3}$ \\ ${ }^{1,2}$ Komputerisasi Akuntansi, Universitas STEKOM, Semarang \\ ${ }^{3}$ Sistem Komputer, Universitas STEKOM, Semarang
}

\begin{tabular}{|c|c|}
\hline ARTICLE INFO & ABSTRACT \\
\hline $\begin{array}{l}\text { Article history: } \\
\text { Received } 30 \text { November } 2020 \\
\text { Received in revised form } 2 \text { Desember } 2020 \\
\text { Accepted } 10 \text { Desember } 2020 \\
\text { Available online } 15 \text { Desember } 2020\end{array}$ & $\begin{array}{l}\text { Dian Wacana Demak Christian Kindergarten- } \\
\text { Kindergarten School, which is one of the agencies } \\
\text { engaged in the science and early childhood } \\
\text { education. The type of data used is qualitative and } \\
\text { quantitative data. The research objective is to design } \\
\text { an effective and efficient school financial } \\
\text { administration recording information system and } \\
\text { design a school financial administration recording } \\
\text { information system that has a system security that } \\
\text { can maintain the correctness of the data. The } \\
\text { research method used is the Borg and Gall R\&D } \\
\text { Development Research model, the Prototyping } \\
\text { System Development Method to produce a product } \\
\text { in the form of a prototype with } 6 \text { stages: Research } \\
\text { and Data Collection, Planning, Initial Product } \\
\text { Development, Product Testing, Product Revision, } \\
\text { Final Trial. } \\
\text { The conclusion from the results of this study is that } \\
\text { this system can facilitate the recording of cash in and } \\
\text { cash out transactions so that there are no mistakes in } \\
\text { recording, users can easily present cash reports more } \\
\text { quickly so that they can minimize recording time } \\
\text { and recording errors, and make it easier for users to } \\
\text { print. cash reports with accurate results so as to } \\
\text { support and speed up decision making. } \\
\text { Keywords: Information Systems, Cash Flow, } \\
\text { Multi User, School. }\end{array}$ \\
\hline
\end{tabular}

\begin{abstract}
ABSTRAK
Sekolah KB-TK Kristen Dian Wacana Demak yang merupakan salah satu instansi yang bergerak dalam bidang ilmu dan pendidikan anak usia dini. Jenis data yang digunakan adalah data kualitatif dan kuantitatif Tujuan penelitian adalah membuat rancangan sistem informasi pencatatan administrasi keuangan sekolah yang efektif dan efisien dan membuat rancangan sistem informasi pencatatan administrasi keuangan sekolah yang memiliki keamanan sistem yang dapat menjaga kebenaran data. Metode penelitian yang digunakan adalah model Penelitian Pengembangan R\&D Borg and Gall, Metode Pengembangan Sistem Prototyping untuk menghasilkan sebuah produk dalam bentuk Prototype dengan 6 tahapan:
\end{abstract}


Penelitian dan Pengumpulan Data, Perencanaan, Pengembangan Produk Awal, Uji Coba Produk, Revisi Produk, Uji Coba Akhir.

Kesimpulan dari hasil penelitian ini adalah sistem ini dapat memudahkan kegiatan pencatatan transaksi kas masuk dan kas keluar sehingga tidak terjadi kekeliruan dalam pencatatan, pengguna dapat dengan mudah menyajiankan laporan kas dengan lebih cepat sehingga dapat meminimalisir waktu pencatatan dan kesalahan pencatatan, dan mempermudah pengguna dalam melakukan pencetakan laporan kas dengan hasil yang akurat sehingga dapat menunjang dan mempercepat pengambilan keputusan.

\section{Kata kunci : Sistem Informasi, Arus Kas, Multi User, Sekolah.}

\section{Pendahuluan}

Penggunaan perangkat komputer yang menjadi sebuah kebutuhan dalam pengolahan data untuk menjadi suatu informasi yang penting menjadikan sistem informasi berbasis teknologi dan komputer sebagai sarana pemberi informasi keuangan dalam suatu instansi. Cash flow (aliran kas) merupakan sejumlah uang kas yang keluar dan yang masuk sebagai akibat dari aktivitas perusahaan. Dengan kata lain, aliran kas terdiri dari aliran masuk dalam perusahaan dan aliran kas keluar perusahaan serta saldo disetiap periode. Arus kas masuk adalah arus kas yang terjadi dari kegiatan transaksi yang melahirkan keuntungan kas yang di sebut penerimaan kas sedangkan arus kas keluar adalah arus kas yang terjadi dari kegiatan transaksi yang mengakibatkan biaya pada kas yang disebut pengeluaran kas (Maruli, 2013). Sistem pencatatan keuangan KB-TK Kristen Dian Wacana saat ini masih dilakukan secara manual yaitu dengan cara menulis pada buku disetiap pos kas. Masing-masing bagian yang bertanggung jawab melakukan pencatatan pada buku pos kas harus menyerahkan buku pos kas kepada Bendahara KB-TK pada setiap akhir bulan. Buku pos kas yang telah diserahkan kepada Bendahara KB-TK merupakan dasar untuk melakukan pencatatan ulang secara manual pada buku rekapitulasi kas dan kemudian dilakukan pencatatan pada Microsof Excel dimasing-masing sheet sesuai dengan pos kas yang ada. Dari sheet-sheet pos kas inilah yang akan diolah kembali untuk menjadi laporan keuangan. Sebelum melakukan pencetakan laporan keuangan, data laporan berupa file Microsof Excel yang telah dibuat harus terlebih dahulu dilaporakan kepada Finance Accounting Management (FAM) untuk dikoreksi dan kemudian mendapat ijin pencetakan laporan. Pelaporan file ini dilakukan dengan cara memberikan copy file menggunakan flashdisk dan harus membuka dari sheet per sheet untuk memperoleh laporan-laporan keuangan yang dibutuhkan. Setelah FAM mengkoreksi file laporan dan memberi ijin untuk melakukan pencetakan, Bendahara KB-TK Kristen Dian Wacana akan melakukan pencetakan laporan dan menyusun hasil cetak laporan kemudian menandatangani laporan keuangan yang telah dibuat dilengkapi dengan tanda tangan Kepala Unit, FAM dan Manager Operasional aplikasi yang akan digunakan dengan sistem informasi berbasis multi user ini memungkinkan pengguna lebih dari satu dalam mengakses sistem komputer dalam waktu yang bersamaan, sehingga sistem informasi yang ada pada komputer yang dimiliki sekolah dapat digunakan secara optimal. Sistem ini juga akan dilengkapi dengan hak akses yang diberikan kepada masing-masing pihak terkait, seperti: Finance Accounting Management (FAM), kepala unit KB-TK, bendahara KB-TK, dan guru yang menjadi koordinator kas atau pemegang pos kas sehingga keamanan data keuangan menjadi terjamin dan tidak akan terjadi manipulasi data. Dengan demikian sistem informasi yang hendak dibangun ini diharapkan dapat memperbaharui sistem yang sudah ada sehingga setiap pihak terkait dapat dengan mudah mengakses informasi keuangan dengan cepat dan tepat serta dapat meminimalisir kesalahan pencatatan

\section{Landasan Teori \\ a. Pengertian Kas}

Kas adalah salah satu unsur modal kerja yang paling tinggi tingkat likuiditasnya. Dengan demikian kas merupakan komponen modal kerja yang paling tinggi tingkat likuiditasnya, berarti bahwa semakin besar jumlah kas yang dimiliki perusahaan akan semakin tinggi pula tingkat likuiditasnya. Tetapi perusahaan yang mempunyai tingkat likuiditas yang tinggi karena adanya kas yang berlebihan, berarti tingkat perputaran kas tersebut rendah dan mencerminkan kelebihan investasi dalam kas. Makin tinggi tingkat perputaran kas berarti makin cepat kembalinya kas masuk pada perusahaan. Dengan demikian kas akan dapat dipergunakan kembali untuk membiayai kegiatan operasional sehingga tidak mengganggu kondisi keuangan perusahaan. (Bambang, 2011)

JURNAL ILMIAH KOMPUTERISASI AKUNTANSI Vol. 13, No. 2, Desember 2020: $1-10$ 


\section{b. Arus Kas}

Cash Flow (aliran kas) merupakan sejumlah uang kas yang keluar dan yang masuk sebagai akibat dari aktivitas perusahaan. Dengan kata lain, aliran kas yang terdiri dari aliran masuk dalam perusahaan dan aliran kas keluar perusahaan serta saldonya setiap periode. (Maruli, 2013)

Laporan Arus Kas adalah suatu laporan tentang aktivitas penerimaan dan pengeluaran kas perusahaan selama suatu periode tertentu, beserta penjelasan tentang sumber-sumber penerimaan dan pengeluaran kas tersebut. (Ikit, 2015). Tujuan menyajikan laporan arus kas adalah memberikan informasi yang relevan tentang penerimaan dan pengeluaran kas atau setara kas dari suatu perusahaan pada suatu periode tertentu. (Ikit, 2015)

\section{c. Pengertian Informasi}

Sistem Informasi adalah suatu sistem didalam suatu organisasi yang mempertemukan kebutuhan pengolahan transaksi harian, mendukung operasi, bersifat manajerial dan kegiatan strategi dari suatu organisasi dan menyediakan pihak luar tertentu dengan laporan-laporan yang dibutuhkan. (Jeperson, 2015)

\section{d. Laporoan Keuangan}

Laporan Keuangan merupakan ringkasan dari suatu proses transaksi-transaksi keuangan yang terjadi selama periode yang bersangkutan. (Yayah, 2016). Macam-macam Laporan Keuangan (Muhammad Arifin, dkk, 2012)

Laporan Laba Rugi, yakni ikhtisar bagian pendapatan dan beban selama tempo/periode tertentu, setiap bulan atau setahun. Laporan Ekuitas, yaitu ikhtisar atas perubahan modal/ekuitas selama periode tertentu. Neraca, yakni laporan sistematis mengenai harta, kewajiban dan modal/ekuitas selama periode tertentu. Laporan Arus Kas, yakni ikhtisar penerimaan dan pembayaran kas selamaperiode tertentu.

e. $M y S Q L$

MySQL (My Structure Query Language) adalah salah satu Data Base Management System (DBMS) dari sekian banyak DBMS seperti Oracle, MS SQL, Postagre SQL, dan lainnya. MySQL berfungsi untuk mengolah database menggunakan bahasa SQL. MySQL bersifat open source sehingga kita bisa menggunakannya secara gratis. Pemrograman PHP juga sangat mendukung atau support dengan database MySQL. (Anhar, 2010)

\section{f. Borland Delphi 7}

Bahasa pemrograman Delphi adalah pemrograman berorientasi objek yang merupakan pengembangan dari bahasa pemrograman pascal. Pascal adalah pemrograman berbasis DOS yang dibuat pada tahun 1971 oleh Niklaus Wirth dari Swiss. Kata pascal diambil dari nama matematikiawan dan ahli filsafat dari Perancis, yaitu Blaise Pascal yang lahir tahun 1623 dan meninggal tahun 1662. Pascal dirilis tahun 1983 oleh Borland International, salah satu perusahaan software terkemuka di California. Pada tahun 1993, Borland International mengembangkan bahasa pemrograman pascal yang bersifat visual yang disebut Delphi dan resmi dipasarkan pada tahun 1995. Pemrograman ini dibuat secara modern yang berjalan di Sistem Operasi Windows mulai dari versinya yang pertama yaitu Delphi 1 dan ditahun-tahun berikutnya Delphi terus dikembangkan mengikuti kebutuhan jaman. (Kani, Firmansyah, dan Sufandi, 2010)

\section{Metode Penelitian}

Metodologi penelitian adalah metode yang akan digunakan dalam melakukan penelitian. Dalam penyusunan skripsi ini akan digunakan metode sebagai berikut:

a. Obyek Penelitian

KB-TK Kristen Dian Wacana di Perumahan Plamongan Indah Blok I.6 Kel. Batursari Kec.Mranggen Kota Demak

1. Jenis Data

Berdasarkan sumber data yang diperoleh, maka jenis data dapat menggunakan dua sumber dara yaitu :

Data Primer adalah data yang diperoleh dari penelitian secara langsung terhadap objek penelitian yaitu memasukkan data pembayaran siswa di sekolah KB-TK Kristen Dian Wacana di Perumahan Plamongan Indah Blok I.6 Kel. Batursari Kec.Mranggen Kota Demak

2. Data Sekunder adalah data yang terlebih dahulu dikumpulkan dan dilaporkan oleh orang, dari literatur perusahaan atau yang diperoleh dari perpustakaan berupa pengertian dan konsep dan definisi-definisi, meliputi kegiatan perusahaan, struktur organisasi perusahaan.

b. Metode pengumpulan data

Dalam pembuatan proposal ini perlu dilakukan suatu usaha pengumpulan data, dan data tersebut yang akan digunakan sebagai alat untuk memecahkan masalah yang ada didalamnya. Untuk itu diperlukan beberapa metode yang diperlukan dalam pengumpulan data tersebut, yaitu:

1. Pengamatan (observasi) 
Untuk hal ini penulis mengadakan pengamatan langsung mengenai pemasukan dan pegeluaran kas KB-TK Kristen Dian Wacana di Perumahan Plamongan Indah Blok I.6 Kel. Batursari Kec.Mranggen Kota Demak

2. Wawancara (interview)

Untuk hal ini penulis melakukan pencarian data melalui Tanya KB-TK Kristen Dian Wacana di Perumahan Plamongan Indah Blok I.6 Kel. Batursari Kec.Mranggen Kota Demak

seperti sistem pencatatan penerimaan dan pengeluaran kas hingga menjadi suatu laporan, meringkas proses pemindahan data dari buku besar hingga menjadi laporan cash flow.

Studi kepustakaan

Studi kepustakaan dilakukan untuk mendapatkan data agar permasalahan dapat diselesaikan secara teoritis, menunjang data-data yang telah diperoleh dari metode lapangan serta menguatkan pendapat dalam menganalisa hasil penelitian lapangan sehingga permasalahan yang ada dapat diselesaikan dengan baik.

3. Metode pengembangan sistem

Metode yang digunakan adalah prototyping yaitu satu versi dari sebuah sistem potensial yang memberikan ide bagi para pengembang dan calon pengguna, bagaimana sistem akan berfungsi dalam bentuk yang telah selesai

dalam bentuk yang telah selesai.

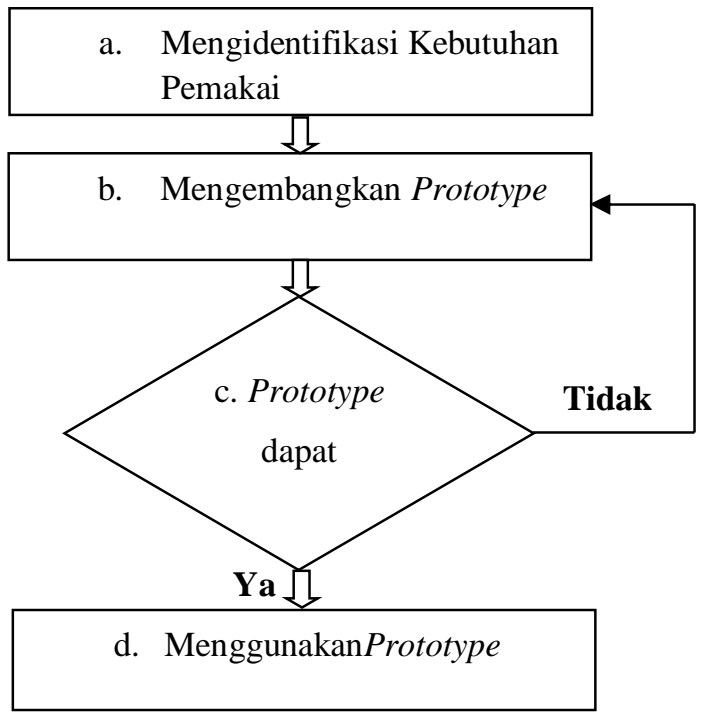

Gambar 1 Pembuatan prototyping evolusioner

(Yulia dan Dewi, 2015)

4. Mengindetifikasi kebutuhan pengguna

5. Mengumpulkan masalah-masalah yang terjadi Mengindetifikasi kebutuhan pengguna

Mengumpulkan masalah-masalah yang terjadi di KB-TK Kristen Dian Wacana di Perumahan Plamongan Indah Blok I.6 Kel. Batursari Kec.Mranggen Kota Demak tentang Sistem penerimaan dan pengeluaran kas hingga menjadi suatu laporan, meringkas proses pemindahan data dari buku besar hingga menjadi laporan cash flow.

6. Membuat sebuah prototyping

Menyiapkan rancangan Flowchart, DFD, Normalisasi, ERD, Borland Delphi 7, User Interface (Form), database $M y S Q L$.

7. Persetujuan pengguna

Setelah materi terkumpul semua tahapan selanjutnya adalah Perancangan Sistem Informasi Akuntansi Penerimaan dan Pengeluaran Kas dengan membuat desain aplikasi yang berisi : Flowchart, DFD, Normalisasi, ERD, Borland Delphi 7, User Interface (Form), database MySQL, dan pembuatan kode aplikasi.

JURNAL ILMIAH KOMPUTERISASI AKUNTANSI Vol. 13, No. 2, Desember 2020 : 1 - 10 
8. Mengunakan prototyping

Perancangan Sistem Informasi Arus Kas, tapi apabila valid program dapat digunakan sebagai produk prototype sistem informasi yang nanti dapat di implementasikan kepada user yaitu Finance Accounting Management, Kepala Unit KB-TK, Bendahara KB-TK, Guru Yang Menjadi Koordinator Kas Setelah melalui tahap uji coba dan hasilnya baik maka prototyping siap digunakan oleh user.

tentang Sistem Arus Kas hingga menjadi suatu laporan, meringkas proses pemindahan data dari buku besar hingga menjadi laporan cash flow.

9. Membuat sebuah prototyping

Menyiapkan rancangan Flowchart, DFD, Normalisasi, ERD, Borland Delphi 7, User Interface (Form), database $M y S Q L$.

10. Persetujuan pengguna

Setelah materi terkumpul semua tahapan selanjutnya adalah Perancangan Sistem Informasi Akuntansi Penerimaan dan Pengeluaran Kas dengan membuat desain aplikasi yang berisi : Flowchart, DFD, Normalisasi, ERD, Borland Delphi 7, User Interface (Form), database MySQL, dan pembuatan kode aplikasi.

11. Mengunakan prototyping

Perancangan Sistem Informasi Arus Kas, tapi apabila valid program dapat digunakan sebagai produk prototype sistem informasi yang nanti dapat di implementasikan kepada user yaitu Finance Accounting Management, Kepala Unit KB-TK, Bendahara KB-TK, Guru Yang Menjadi Koordinator Kas dengan penambahan hak akses user untuk pembatasan pemakai sistem informasi. Setelah melalui tahap uji coba dan hasilnya baik maka prototyping siap digunakan oleh $u s e r$.

\subsection{Bahan Penelitian}

1.Aplikasi ini dibangun dengan perangkat lunak pengembang yaitu :

a. Sistem Operasi Windows 2007 Ultimate 32-bit

b. Software Borland Delphi 7 sebagai media desain

c. Database Sql Server 2000 sebagai media penyimpanan data

2.Spesifikasi hardware yang digunakan untuk membangun sistem tersebut minimal terdiri dari :

a. Empat komputer portable dengan prosesor intel(R) Atom(TM) CPU N570 @ $1.66 \mathrm{GHz}$ $1.67 \mathrm{GHz}$

b. Random Access Memory $2084 \mathrm{MB}$

c. Hard Disk Drive 320 GB

d. Kabel UTP

e. Connector RJ45

3.Aplikasi ini terdiri dari beberapa form :

a. Input Data

1) Form login user

2) Form master

a) Form master pengguna

b) Form master siswa

c) Form master guru

d) Form password

3) Form transaksi

a) Form Uang Sekolah

b) Form Dana Pengembangan Institusi

c) Form Uang Seragam

d) Form Uang Paket Buku

e) Form Uang Kedinasan

f) Form Uang Kegiatan

g) Form Uang Lasy

h) Form Uang Cepi

i) Form Oprasional

b. Output Data / Hasil akhir berupa Laporan

1) Laporan Uang Sekolah

2) Laporan Dana Pengembangan Institusi

3) Laporan Uang Seragam 

4) Laporan Uang Paket Buku
5) Laporan Uang Kedinasan
6) Laporan Uang Kegiatan
7) Laporan Uang Lasy
8) Laporan Uang Cepi
9) Laporan Oprasional
10) Laporan Kas Masuk
11) Laporan Kas Keluar

4. Perangkat lunak dari perancangan yang akan dihasilkan berupa aplikasi berbasis multi user yang memiliki tujuan Informasi kepada:
a. User
: menginput data kas
b. Pimpinan
: laporan evaluasi dari semua data kas

\subsection{Desain Penelitian}

Context Diagram
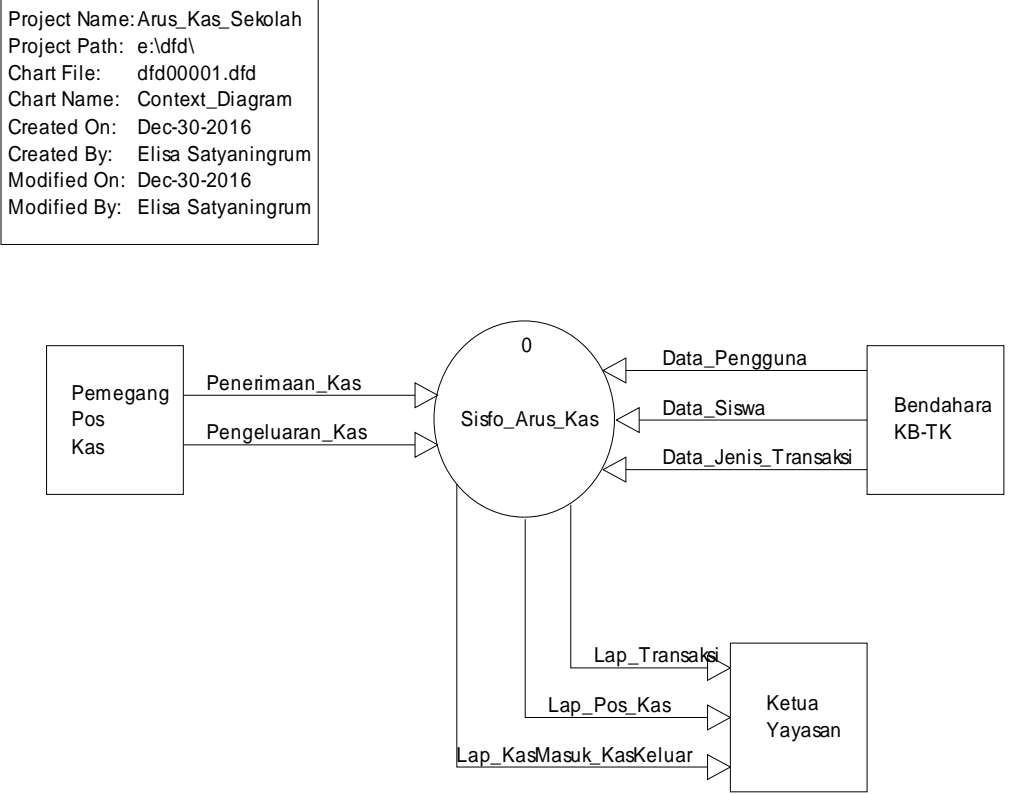

Gambar 2 Context Diagram

Context Diagram menunjukkan sistem Informasi Arus Kas pada Sekolah KB-TK Kristen Dian Wacana. Unit yang terkait meliputi Pemegang Pos Kas, Bendahara KB-TK dan Ketua Yayasan. Data yang diinput meliputi Data Pengguna, Data Siswa dan Data Jenis Transaksi, sedangkan data output meliputi Laporan Transaksi, Laporan Pos Kas dan Laporan Kas Masuk dan Kas Keluar.

\subsection{Perancangan}

Membuat perancangan dimana langkah-langkahnya adalah :

1) Menentukan tujuan sistem

2) Membuat spesifikasi produk

3) Menyusun gambaran sistem rancangan program berupa Basis Data, Normalisasi, Diagram Konteks, Flowchart, DFD, ERD dan perancangan database serta perancangan user interface form-form tampilan yang akan dipergunakan dalam aplikasi tersebut. Membuat program, yaitu dengan pembuatan source code dengan menggunakan bahasa pemrograman Borland Delphi 7. 


\section{Hasil dan Pembahasan}

\section{Form Login}

Fungsi : Untuk pengamanan aplikasi dengan pembagian hak akses

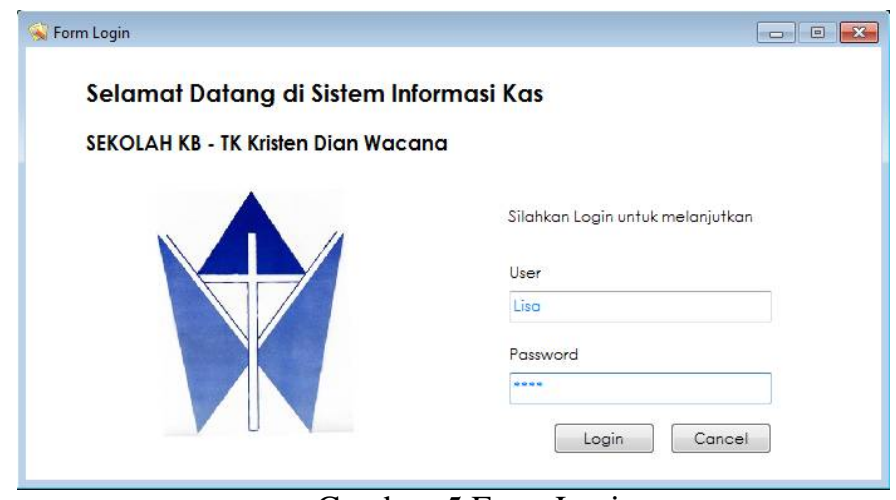

Gambar 5 Form Login

\section{Form Menu Utama}

Fungsi : Untuk Mempermudah User dalam membuka Form Master, Transaksi dan Laporan-laporan.

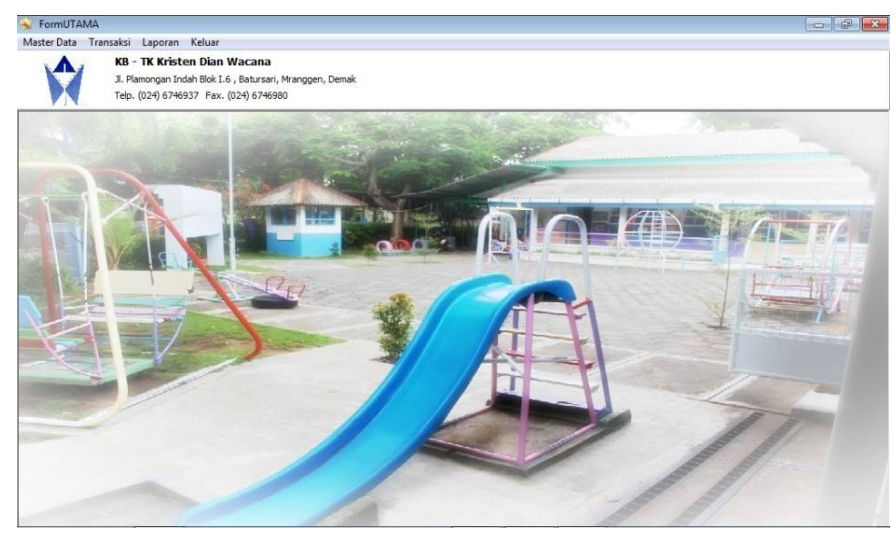

Gambar 6 Form Menu Utama

\section{Form Master Pengguna}

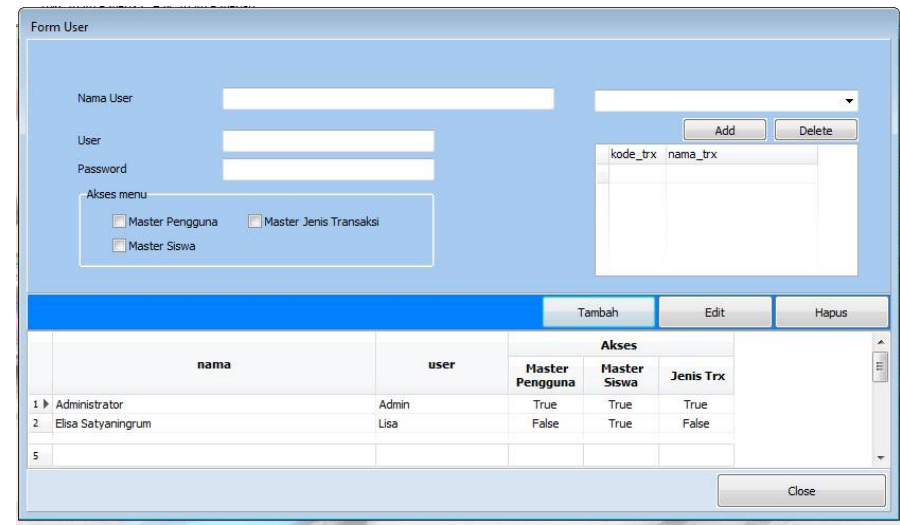

Gambar 7 Form Master Pengguna 


\section{Form Master Siswa}

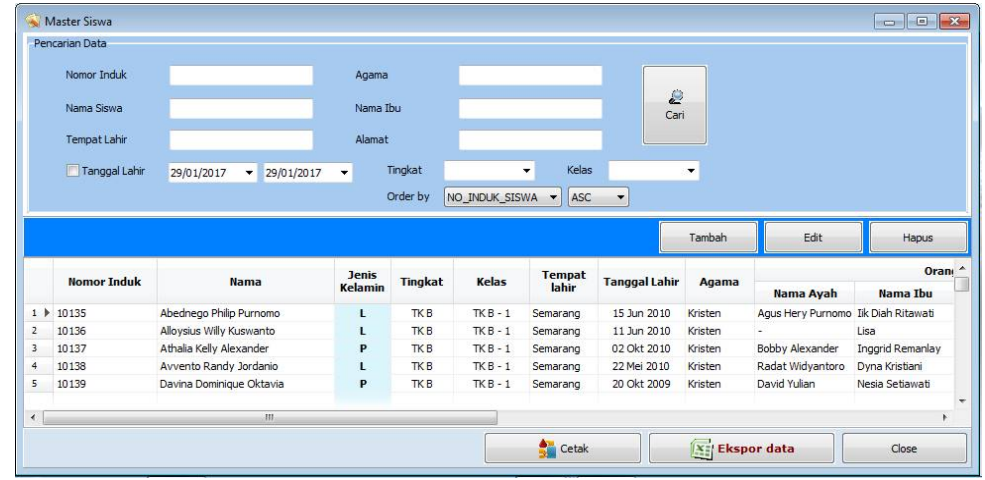

Gambar 8 Form Master Siswa

\section{Form Master Transaksi}

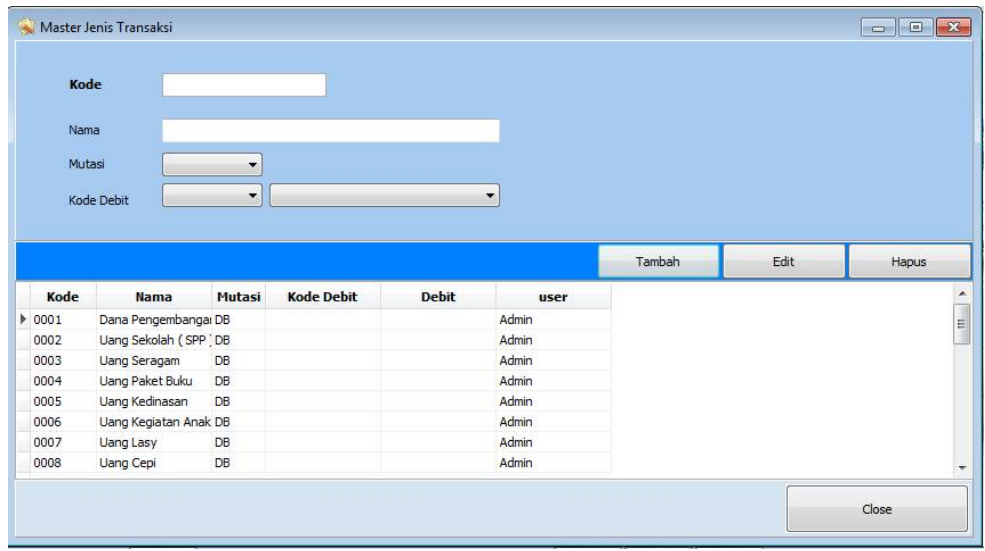

Gambar 9 Form Master Transaksi

\section{Form Laporan Transaksi}

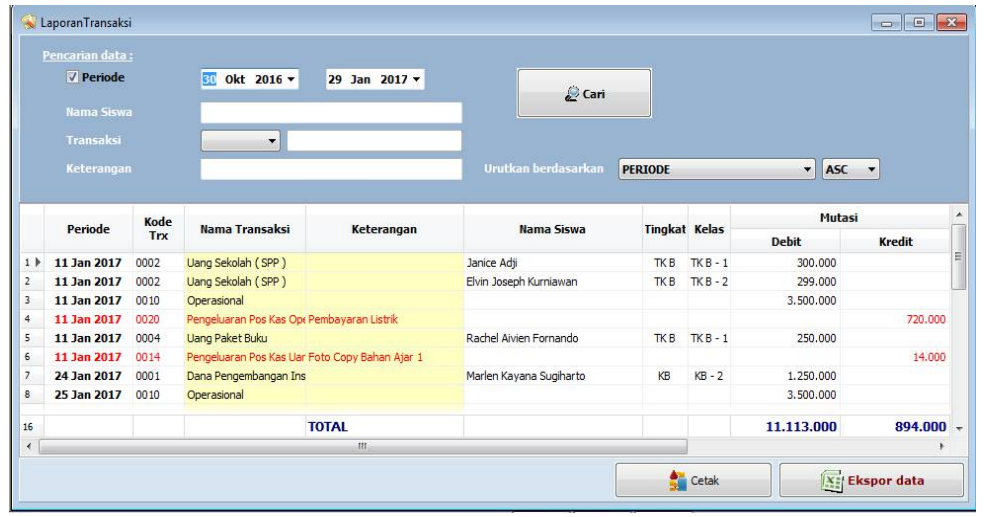

Gambar 10 Form Laporan transaksi 
7. Form Laporan Pos Kas

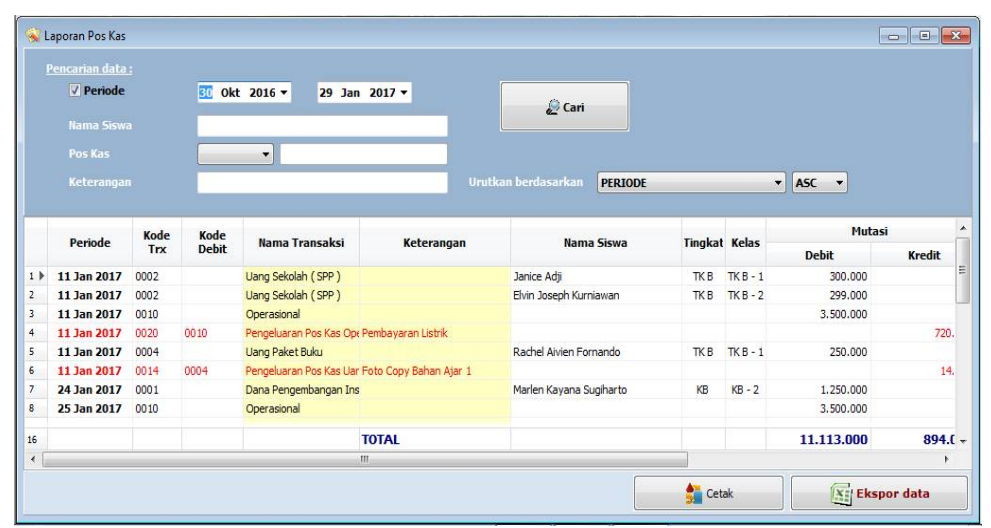

Gambar 11 Form Laporan Pos Kas

\section{Form Laporan Kas masuk dan Kas Keluar}

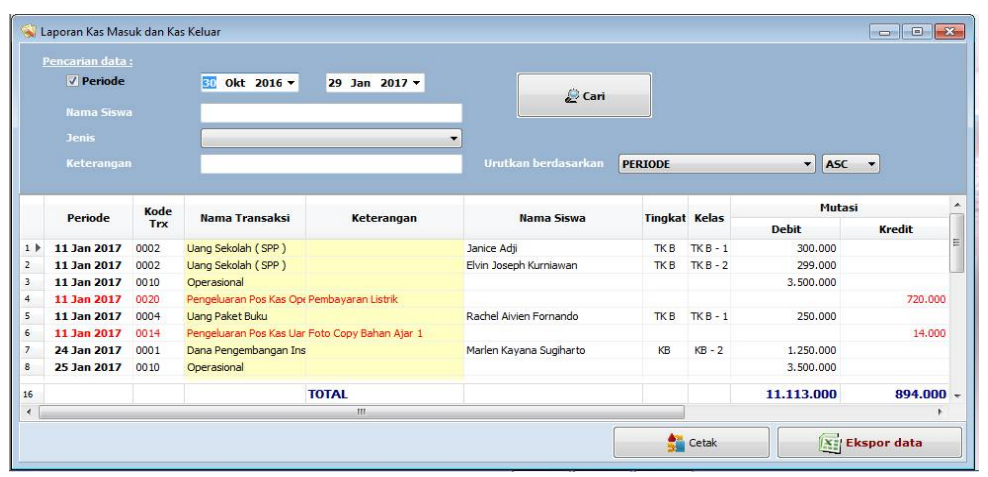

Gambar 12 Form Laporan Kas Masuk dan Kas Keluar

\section{Kesimpulan}

Berdasarkan penelitian dan penyusunan skripsi yang penulis lakukan dengan judul "Sistem Informasi Arus Kas Berbasis Multi User Pada Sekolah KB-TK Kristen Dian Wacana”. Ada beberapa kesimpulan yang dapat penulis peroleh yaitu Dengan adanya uji coba validasi yang dilakukan oleh pakar internal dan pemakai (user) dapat membantu produk yang dibuat penulis menjadi lebih baik dengan saran-saran perbaikan yang diberikan. Dengan adanya sistem informasi arus kas yang terkomputerisasi, user lebih mudah melakukan kegiatan pencatatan transaksi kas masuk dan kas keluar karena seluruh transaksi tersimpan dan terhubung dalam satu database serta dilengkapi dengan hak akses untuk beberapa user yang berkepentingan menggunakan sistem ini, dengan adanya sistem informasi arus kas yang diusulkan, maka penyajian laporan kas menjadi lebih cepat sehingga dapat meminimalisir waktu pencatatan dan kesalahan pencatatan dan dengan adanya sistem informasi arus kas, pengguna akan lebih mudah dalam melakukan pencetakan laporan kas dengan hasil yang akurat. 
Daftar Pustaka:

Anhar, 2010; "PHP dan MySql Secara Otodidak", Jakarta: Media Kita.

Bambang Riyanto, 2011; "Dasar-Dasar Pembelanjaan Perusahaan (Edisi4)”, Yogyakarta: BPFE.

Ikit, 2015; ”Akuntansi Penghimpunan Dana Bank Syariah", Yogyakarta: Deepublish

Jeperson Hutahaean, 2015; "Konsep Sistem Informasi”, Yogyakarta:Deepublish.

Kani, Firmansyah, dan Sufandi, 2010; "Pemrograman Database Menggunakan Delphi (Delphi Win32 dan MySQL 5.0 Dengan Optimalisasi Komponen ZeosDBO)", Jakarta: Graha Ilmu.

Maruli Pardamean, 2013; "Mengelola Kebun Dan Pabrik Kelapa Sawit Secara Profesional”, Jakarta Timur: Penebar Swadaya Grup.

Yayah Pudin Shatu, 2016; "Kuasai Detail Akuntansi Laba dan Rugi”, Jakarta: Lembar Langit Indonesia.

Yulia Djahir dan Dewi Pratita, 2015; ”Bahan Ajar Sistem Informasi Manajemen”, Yogyakarta: Deepublish. 